After a brief introduction, the various types of blood groups are described which for many people will be rather formidable reading. There are so many systems of blood groups known now that it is not surprising that this comparatively small book of 150 pages contains 265 references to the literature. The anthropological and the medicolegal aspects of blood grouping are briefly mentioned.

\section{HAEMATOLOGISCHER ATLAS}

By Dr. Horst StobBe. 304 pp. AkademieVerlag, Berlin. 1959.

This new atlas of haematology published in Berlin has beautifully reproduced colour photomicrographs and some photographs in black and white, including some phase contrast pictures. The various cell systems are described and illustrated in the orthodox manner and the practical laboratory techniques for haematological studies are fully described. This well produced book does real credit to author, publisher and printer.

\section{ANATOMY OF THE HUMAN BODY}

By R. D. LOCKHaRT, M.D., Ch.M., F.R.S.E., G. F. Hamilton, B.Sc., M.B., Ch.B., and F. W. Fyfe, M.A., M.B., Ch.B. Pp. ix +697 , fully illustrated. London: Faber \& Faber Ltd. I959. £5 5s.

It has been the authors' intention to reduce the burden of the student of anatomy and to achieve this they aimed to shorten the text to about half the length found in standard texts. The shortening was to be achieved by brevity and the omission of repetition and by the very extensive use of illustrations in the belief that 'a little picture is worth a million words.' Much repetition has indeed been avoided and the book is little less than half the length of Gray's ' Anatomy.'

It is doubtful, however, if the Chinese proverb quoted was intended to apply to little pictures accompanied by some hundreds of descriptive words and it is a general criticism of the book that many of its illustrations are too extensively labelled. This applies especially in the section dealing with the nervous system. The diagram illustrating the nervous control of the pupil is itself necessarily complex and it is accompanied by captions totalling rather more than 600 words; many of these captions are themselves repetition of what has already appeared in the text. The figure illustrating the autonomic nervous supply of glands in the head rivals a London Transport map in complexity and, like others dealing with the autonomic system, is on too small a scale to allow easy understanding or even recognition of its parts. It is unlikely that such figures as these will lighten any student's burden, although careful study of them, if sufficiently prolonged, will be worth while.

Most of the other sections of the book are dealt with rather conventionally and many of the illustrations are beautifully executed. It is a sensible and unusual arrangement, however, to describe joints in sequence with the bones that form them, while in the section on muscles many excellent photo- graphs serve to emphasize how much may be learned from surface anatomy without suggesting that it is a separate study unrelated to dissectingroom observations. While much of the overall shortening of the book has been obtained by the virtual exclusion of histology and embryology, more has been achieved by brevity and condensation, so that very little factual information on gross adult anatomy has been omitted.

It is a unique feature of the book that many peripheral nerves are dealt with, in effect, only by figures and lengthy captions. All relevant information regarding such nerves is immediately at hand, but the captions are set out around and between the figures, utilizing every smallest bit of space, and cannot be read with any facility.

The authors' policy of drastic shortening without significant omissions of fact has led to the production of a book packed with information which, in many places, requires more than ordinary resolution to read. It may be supposed that few of the larger anatomical texts are read for pleasure, but this book may certainly be read usefully for information.

The burden upon the student of anatomy is placed there not so mucy by his books as by the requirements, real or supposed, of his examiners. It is becoming fashionable for examiners for and M.B. to demand less extensive knowledge of "irrelevant detail 'than in years past, but the full benefit of this relaxation has yet to be felt by students unable to gauge what will be 'irrelevant' when it comes to a viva. For the higher qualifications the standard of anatomical knowledge required is still extremely high. This new book provides the information required for anatomical examination at either level. It is very doubtful whether this information can be extracted more easily from this than from the standard texts, despite that it is so much shorter and that so much care and effort have been expended upon it.

\section{THE PATHOLOGY AND MANAGEMENT OF PORTAL HYPERTENSION}

By R. Mulnes Walker, M.S., F.R.C.S. Pp. vii + I 13 , illustrated. London: Edward Arnold Ltd. I959. $35 \mathrm{~s}$.

The book is a short monograph by Professor Milnes Walker, an acknowledged expert on the surgery of portal hypertension, and in it he summarizes his experience in over 200 cases of portal hypertension. There are chapters on the anatomy and physiology of the portal system, and also on the pathology and clinical aspects of portal disease. The section on experimental surgery is brief, but many references to the literature on this subject are appended. Operation details are dealt with concisely and of particular value is the section on the management of haemorrhage from oesophageal varices. The text is easy to read and liberally illustrated with excellent colour plates, photographs and diagrams.

This monograph should prove of particular value to the general surgeon who wishes a concise and accurate analysis of this important subject. J.R.K. 